\title{
Investigating Prospective Preservice Teacher's Misconceptions of Direct Current Electric Circuits
}

\author{
Neni Hermita \\ Universitas Riau, \\ Pekanbaru, Indonesia \\ nenihermita1@yahoo.com
}

Isjoni

Universitas Riau,

Pekanbaru, Indonesia

Andi Suhandi

Universitas Pendidikan Indonesia

Bandung, Indonesia

Ernawulan Syaodih

Universitas Pendidikan Indonesia

Bandung, Indonesia

\author{
Achmad Samsudin \\ Universitas Pendidikan Indonesia \\ Bandung, Indonesia
}

\author{
Chaerul Rochman \\ UIN Sunan Gunung Djati \\ Bandung, Indonesia \\ chaeruldmsuin@yahoo.com
}

\author{
Fitria Rosa \\ SMAN 1 Peranap \\ Riau, Indonesia
}

\begin{abstract}
Investigative research had been carried out to get a picture of misconceptions that occurred in primary school teachers candidate dealing with the direct current electrical circuit. The method used in this study is descriptive method conducted on prospective primary school teachers of a bachelor degree. The number of respondents involved in the study is 41 students of PGSD FKIP University of Riau. The data collection was done by administering test conception using Four Tier Test format. The result of the identification indicated that there were several misconceptions related circuit direct current electricity concept, These include: 1) The electric current appears on a conductor as a result of the movement of positive charges in the conductor from the positive pole of the battery to the negative pole of the battery 2) in the electric circuit the electrons flow with very high speeds approaching the speed of light, 3 ) addition of batteries in series electrical circuit can increase the number of electrons that electric current in the circuit becomes larger.

Recommendations from this research are the need to design a lecture that facilitates the changing conception of misconceptions that occurs in the minds of prospective students of primary school teachers into a conception of science, however, because they are more candidates are required to have an understanding intact and free from misconceptions. Result of research found that the test can analyze and classify students into understanding the concept about $2,03 \%$, experience misconceptions about $40 \%$, not understand about $53,74 \%$ and stay in parallel conception about $3,66 \%$
\end{abstract}

Keywords-Misconceptions; direct current electrical circuit; elementary education

\section{INTRODUCTION}

Today misconceptions have been one of substantial domain research in science education. Misconceptions among students on difficult and abstract science concept can be met globally. Students which experience misconception difficult to change from wrong to correct knowledge. Students' misconception can only be transformed into the correct concept next to scientific conception. If students have inside motivation to change which is known as conceptual change. As for misconceptions, conceptual change has also become one of the most fundamental research domains in the study of Science Education. The first conceptual change models, developed by refference [1] has become the most influential theory since the beginning up to now. This conceptual model has been developed to describe the change of learning as the relationship between existing knowledge with new knowledge that leads to the four conditions, namely: dissatisfaction, clarity (intelligibility), the sensible thing (plausibility) and success (fruitfulness). Various studies as a base model on conceptual change approach involving cognitive conflict in it can be found in Ref. [2]; [3]; and [4]. Cognitive conflict strategy is more emphasis on students' self-esteem instability (destabilizing the student's confidence) on specific concepts through experience opposites as a discrepant event. All models of conceptual change approach had been proven working effectively and optimally when researchers conducted a diagnosis prior to the 
respondent that would be the subject of subsequent research. To solve this issue, researchers have developed a Four Tier Test instrument in the form of three-tier test ( $\mathrm{T}$ three). Four Tier Test instrument consists electric current concept. In this article, the researchers focus on Four Tier Test instrument to diagnose conception of pre-service elementary school teachers to the concept of electric current learned in Basic science concept. Four Tier Test instrument development is modified from the structure of instrument developed by Vatansever [5] that made up the instrument in format of the three-tier test type, whereas the development of each tier (level) has been developed and compiled in the first tier of several standard tests as in [5]; [6]; [7]; and [8]. Three Tier Test organized into three levels (tiers), namely: the first tier to the standard question in the form of multiple choice with five choices, the second tier is given a blank for an explanation of the chosen answer and third tier contains level of confidence (confidence rating) of the answers, namely: very confident, not confident and do not know.

\section{METHODS}

An investigation method was conducted to obtain the profiles of 41 pre-service elementary school teachers The subject research was tested by using four tier test instrument within 60 minutes duration of lecturing. The survey was conducted prior the students learned about electric current in the course of Basic Science Concept. The research was accompanied by the academic year 2016/2017 at the Teachers Training and Education, University of Riau.

The following is an example a Four tier test instrument.

Sebuah rangkaian listrik yang terdiri dari baterai, lampu, dan kabel disusun seperti pada gambar rangkaian 1. Kemudian pada rangkaian 1 dipasang sebuah baterai yang identik dengan baterai semula secara paralel seperti gambar pada rangkaian 2. Bagaimana nyala lampu setelah ditambahkan sebuah baterai?

A. Nyala lampu tetap sama

B. Lampu akan bertambah terang

C. Lampu akan menjadi redup dari semula

D. Lampu akan menjadi padam

E. Lampu akan terbakar

Tingkat Keyakinan Jawaban

a. Yakin

b. Tidak Yakin
Fig. 2 Rangkaian 2

Penjelasan yang tepat sesuai dengan pilihan jawaban yang anda pilih adalah ...

A. Beda potensial pada rangkaian bertambah

B. Beda potensial pada rangkaian berkurang

C. Arus dalam rangkaian berkurang

D. Baterai yang dirangkai paralel tidak akan mengubah beda potensial total pada rangkaian

E.$$
\ldots
$$

Tingkat Keyakinan Alasan

a. Yakin

b. Tidak Yakin

\section{RESULTS AND DISCUSSIONS}

Showed survey research data was the diagnostic result of a profile of student's conceptions that tightening Basic science concept course in the academic year 2016/2017. Quantitative data were expressed in percentages while qualitative data was obtained relevant data about the reasons for the answers on the first level. Here was a profile data of elementary school student's conception to the concept of a direct current electric circuit that was diagnosed using the four-tier diagnostic test such as Table I.

Table I shows that the conception profiles related to preservice teachers were in trouble. This is due to very low percentage (about 2,03\%) of students who understand the concept. Furthermore, students who have misconceptions much higher than the students who understand the concept of an electric field, that is $40,79 \%$ relative to $2,03 \%$. This data become strong "alert" in order to push change previously lecturing in Basic science concept course to scientific conception as already described in ref. [9]. According to ref. $[10,11,12]$, the field concept is needed in while explaining the abstract concept of electricity and magnetism and can serve as a bridge for the concept of electricity and magnetism become more compact to be understood. Besides the concept of the current need special chapter for more emphasis in the study of the concept. Quantitative data in Table I are supported by qualitative data come from students' response (that is their explanation/reason) related to Tier I.

TABLE I. STUDENTS' CONCEPTIONS PROFILE ON DIRECT CURRENT ELECTRIC CIRCUIT

\begin{tabular}{|c|c|c|c|c|}
\hline No & Misconception & $\begin{array}{c}\text { Do Not } \\
\text { Understand }\end{array}$ & $\begin{array}{c}\text { Understanding } \\
\text { The Concept }\end{array}$ & $\begin{array}{c}\text { Parallel } \\
\text { Conception }\end{array}$ \\
\hline 1 & 24,39 & 68,29 & 0 & 7,32 \\
\hline
\end{tabular}

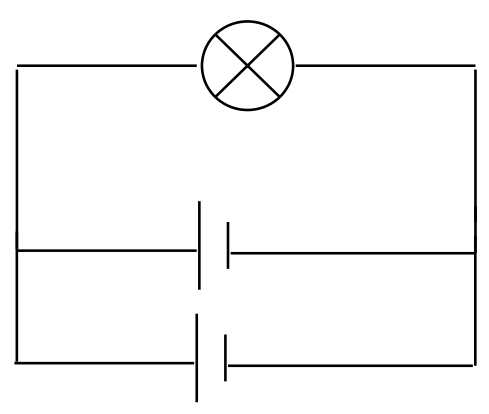




\begin{tabular}{|c|c|c|c|c|}
\hline 2 & 51,22 & 40 & 9,76 & 0 \\
\hline 3 & 40 & 58,54 & 2,44 & 0 \\
\hline 4 & 26,83 & 53,66 & 7,32 & 12,2 \\
\hline 5 & 29,27 & 60,98 & 4,88 & 4,88 \\
\hline 6 & 53,66 & 46,34 & 0 & 0 \\
\hline 7 & 36,59 & 60,98 & 0 & 2,44 \\
\hline 8 & 43,9 & 51,22 & 0 & 4,88 \\
\hline 9 & 29,27 & 70,73 & 0 & 0 \\
\hline 10 & 53,66 & 41,46 & 0 & 4,88 \\
\hline 11 & 58,54 & 36,59 & 0 & 4,88 \\
\hline 12 & 41,46 & 56,1 & 0 & 2,44 \\
\hline$\sum$ & 488,79 & 644,89 & 24,4 & 43,92 \\
\hline$\% \sum$ & 40,79 & 53,74 & 2,03 & 3,66 \\
\hline
\end{tabular}

Researchers recapitulate and selected the top-four alternative answers for each question. Then the reasons from those students for the next development of Four Tier Test instrument. Current structure and format of Four Tier Test are in the form of three-tier (3-level). Next, the authors will change the level II of open essays into four choices of reasons that have been prepared based on a current study with additional one reason in essay format as an open alternative in case students do not choose the four options providing.

\section{CONCLUSION}

Our statistical diagnosis of students' conceptions who learned electric current using Four Tier is: understanding the concept about 2,03\%, experience misconceptions about $40 \%$, not understand about $53,74 \%$ and stay in parallel conception about $3,66 \%$.
[1] G.J. Posner, K.A. Strike, P.W. Hewson, and W. A. Gertzog, "Accommodation of a scientific conception: toward a theory of conceptual change", Science Education, 66, 221-227 (1982)

[2] M.S. Kocakulah and M. Kural, "Investigation of conceptual change about double-slit interference in secondary school physics", International Journal of Environmental \& Science Education 4 (4), 435-460 (2010)

[3] H.C. She and Y.W. Liao, "Bridging scientific reasoning and conceptual change through adaptive web-based learning", Journal of Research in Science Teaching 47 (1), 91-119 (2010)

[4] H. Kucukozer and S. Kocakulah, "Effect of simple electric circuits teaching on conceptual change in grade 9 physics course", Journal of Turkish Science Education, 5 (1), (2008)

[5] O. Vatansever, "Effectiveness of conceptual change instruction on overcome students' misconceptions of electric field, electric potential and electric Potential Energy at tenth-grade level", Thesis Magister, The Graduate School of Natural and Applied Sciences of Middle East Technical University, Turkey, 1999, p. 107

[6] D.P. Maloney, T.L. O’Kuma, C.J. Hieggelke, A.V. Heuvelen, “Surveying students' conceptual knowledge of electricity and magnetism", Phys. Educ. Res., Am. J. Phys. Suppl., 69 (7), s13-s23 (2001)

[7] Bekele Gashe Dega, "Conceptual change through cognitive perturbation using simulations in electricity and magnetism: a case study in Ambo University, Ethiopia”, Dissertation, University of South Africa, South Africa, 2012, p. 1-221

[8] Rhett Allain, "Investigating the relationship between student difficulties with the concept of electric potential and the concept of rate of change", Dissertation, The Graduate Faculty of North Carolina State University, Raleigh, Nort Carolina USA, 2001, p. 1-152

[9] A. G. Sekercioglu, \& M. S. Kocakula, "Grade 10 students' misconception about impulse and momentum", Journal of Turkish Science Education, 5 (2), 47-59 (2008)

[10] Serway Jewett, "Physics for scientists and engineers", Penerbit Thomson Brooks/Cole, California, 2004, p. 706

[11] Samsudin, Suhandi, Rusdiana, Kaniawati \& Custom Fields, Conceptual Change Inventory: A Diagnostic Test Instrument On The Electric Field And Magnetic Field To Diagnose Student's Conceptions. International Journal of Industrial Electronics and Electrical Engineering, ISSN: 23476982 Volume-3, Issue-12, Dec.-2015

[12] Hermita, Suhandi \& Syaodih. Identifikasi Miskonsepsi konsep listrik statis pada mahasiswa calon guru sekolah dasar. Seminar Nasional Pendidikan Dasar, 2016. 